\title{
Further investigation of the HEXA gene intron 9 donor splice site mutation frequently found in non-Jewish Tay-Sachs disease patients from the British Isles
}

\author{
E C Landels, P M Green, I H Ellis, A H Fensom, M M Kaback, J Lim-Steele, \\ K Zeiger, N Levy, $M$ Bobrow
}

\begin{abstract}
In a previous study we found that a TaySachs disease (TSD) causing mutation in the intron 9 donor splice site of the HEXA gene occurs at high frequency in nonJewish patients and carriers from the British Isles. It was found more frequently in subjects of Irish, Scottish, and Welsh origin compared with English origin $(63 \%$ and $31 \%$ respectively). We have now tested, in a blind study, 26 American TSD carriers and 28 non-carriers who have British ancestry for the intron 9 splice site mutation. Six of the carriers and none of the controls were positive for the mutation. All six had Irish ancestry, compared with nine of the 20 other (intron 9 mutation negative) TSD carriers $(p<0.05)$. These results confirm the previously found high frequency of the intron 9 mutation in non-Jewish TSD families of British Isles, particularly Irish, origin, and reinforce the need to screen such families for this mutation. ( $\mathcal{F}$ Med Genet 1993;30:479-81)
\end{abstract}

Tay-Sachs disease (TSD) is a lethal autosomal recessive neurodegenerative disorder caused by deficiency of the lysosomal enzyme hexosaminidase A (Hex A). ${ }^{1}$ The gene (HEXA) encoding the $\alpha$ peptide of Hex $A$ is located on chromosome 15; mutations in this gene causing classic TSD and its variants are found in the general population with an estimated heterozygote frequency of approximately 1 / $166 .^{1}$ However, several populations have an increased carrier frequency, most notably French-Canadians and Ashkenazi Jews. Most classical TSD carriers within these populations are accounted for by a $7.6 \mathrm{~kb}$ deletion (French-Canadians), ${ }^{23}$ a 4 bp insert into exon 11,4 and an intron 12 splice site mutation (Ashkenazi Jews). ${ }^{5-7}$ Many other rarer TSD mutations have been described, often confined to one family.

A guanine (G) to adenine (A) transition in the first nucleotide of intron 9 of the HEXA gene was described ${ }^{8}$ and was found to occur at high frequency in non-Jewish TSD carriers and patients from the British Isles. ${ }^{9}$ Of 24 apparently independent disease alleles, 10 $(42 \%)$ had this mutation, a surprisingly high number considering the heterogeneous nature of the British Isles population. In this small sample, TSD carriers and patients from Scotland, Wales, and Ireland had a higher frequency of the intron 9 mutation compared with those from England $63 \%$ and $31 \%$ respectively). In the present work we have examined, in a blind study, a group of 54 nonJewish American samples (26 TSD carriers and 28 non-carriers), all of whom had British Isles ancestry, for the presence of the intron 9 mutation.

\section{Methods}

Through the computerised files of the California Tay-Sachs Disease Prevention Program, 26 unrelated subjects (previously identified as TSD carriers by enzyme assay), who indicated parental or grandparental origins (one or more) from either England, Scotland, Ireland, or Wales, were selected. Frozen leucocyte pellets or pellet sonicate supernatants from these subjects and 28 non-Jewish non-carriers of similar origins were encoded and sent to London to be tested for the intron 9 mutation.

DNA was extracted from the 54 American samples by phenol-chloroform-isoamyl alcohol precipitation and tested for the intron 9 mutation by PCR amplification and direct sequencing, as previously described. ${ }^{9}$ Samples were scored for the presence or absence of the mutation without previous knowledge of carrier status as determined by enzyme assay. Six were positive, all of whom were from the 'carrier' group.

Some of the samples had been tested previously for other TSD causing mutations, namely the exon 11 insert, the intron 12 splice site mutation, a glycine $e_{269}$ to serine substitution which causes adult onset TSD, and also a benign mutation in exon $7 .^{10}$ All had been negative for all mutations tested. None of the 28 subjects designated non-carriers by enzyme analysis was tested for other mutations.

\section{Results and discussion}

At the time of sampling, each of the 54 subjects listed up to four countries of origin of their grandparents. Table 1 shows the number of intron 9 positive TSD carriers, intron 9 negative TSD carriers, and non-carriers who gave each country as one of those from which their grandparents originated.

As shown in table 2, all six of the intron 9 positive TSD carriers had at least one Irish 
Table 1 Ancestry of grandparents of 26 American TSD carriers tested for the intron 9 mutation.

\begin{tabular}{|c|c|c|c|c|}
\hline & \multicolumn{4}{|c|}{ American TSD carriers } \\
\hline & \multicolumn{2}{|c|}{ Intron $9+$ ve } & \multicolumn{2}{|c|}{ Intron 9 - ve } \\
\hline & $n=6$ & $(\%)$ & $\mathrm{n}=\mathbf{2 0}$ & $(\%)$ \\
\hline Ireland & 6 & $(100)$ & 9 & $(45)$ \\
\hline Scotland & 1 & $(17)$ & 3 & (15) \\
\hline Wales & 0 & $(-)$ & 0 & $(-)$ \\
\hline England & 0 & $(-)$ & 14 & $(70)$ \\
\hline France & 1 & (17) & 2 & (10) \\
\hline Germany & 2 & (33) & 6 & $(30)$ \\
\hline Denmark & 0 & $(-)$ & 1 & (5) \\
\hline Italy & 1 & (17) & 1 & (5) \\
\hline Holland & 1 & (17) & 2 & (10) \\
\hline Czechoslovakia & 1 & (17) & 0 & $(-)$ \\
\hline Poland & 0 & $(-)$ & 1 & (5) \\
\hline Hungary & 1 & (17) & 0 & $(-)$ \\
\hline Israel & 0 & $(-)$ & 1 & (5) \\
\hline
\end{tabular}

Number of subjects having grandparent(s) originating in each country shown. Each subject may have up to four countries of origin.

Table 2 Distribution of the intron 9 mutation among American TSD carriers with or without Irish ancestry.

\begin{tabular}{lccc}
\hline \multirow{2}{*}{$\begin{array}{l}\text { Any Irish } \\
\text { grandparent }\end{array}$} & \multicolumn{2}{c}{ TSD carriers (serum hex A) } & \\
\cline { 2 - 3 } & Intron 9 + ve & Intron 9 - ve & Total \\
\hline Yes & 6 & 9 & 15 \\
No & 0 & 11 & 11 \\
Total & 6 & 20 & 26
\end{tabular}

$\mathrm{p}=0.022$ (exact test, $2 \times 2$ contingency table), that is, less than $5 \%$ probability of seeing this distribution by chance.

grandparent, compared with nine out of 20 (45\%) intron 9 negative TSD carriers. Using the exact test for $2 \times 2$ contingency tables, the probability of this distribution is 0.022 .

Thus, of 25 non-Jewish American TSD carriers, selected on the basis of a declared British Isles ancestry (that is, at least one grandparent from the British Isles), six (23\%) were positive for this specific intron 9 mutation. This confirms the previously noted high frequency of the mutation among non-Jewish TSD carriers of UK origin. ${ }^{9}$ A significantly higher proportion of intron 9 positive TSD carriers had grandparents of Irish origin compared with intron 9 negative TSD carriers. The question arises of what proportion of Irish TSD chromosomes carry this mutation?

Only four mutations causing classic infantile TSD in patients with some Irish ancestry have been published and only one $\left(\mathrm{C}_{409}\right.$ to $\mathrm{T}$ in exon 3) which was definitely inherited through the parent with Irish ancestry. ${ }^{11}$ We have attempted to find further TSD cases in Ireland and have been referred one affected child who, on testing, was found to be homozygous for the intron 9 mutation (unpublished data). Thus we have now tested five apparently unrelated disease alleles from three Irish subjects (one is the aforementioned TSD patient; another TSD patient and an obligate TSD carrier were reported in our previous study ${ }^{9}$ ). Four of the five $(80 \%)$ have the intron 9 mutation. In the present study, of the 15 TSD carriers who listed Ireland as a country of origin of grandparents, six $(40 \%)$ had the intron 9 mutation. However, some of those 15 carriers are likely to have inherited the TSD mutation from one of their other grandparents of non-Irish origin.
Only two of the TSD carriers gave Ireland as the sole country of origin of grandparents, and one of these subjects was positive for the intron 9 mutation. These results are compatible with the hypothesis that most TSD carriers from Ireland have the intron 9 mutation.

Other studies have now reported the frequent occurrence of the intron 9 mutation in non-Jewish TSD patients. Two studies of TSD patients or carriers of central or western European origin have found that the intron 9 mutation accounts for $16 \%,{ }^{12}$ or $11 \%{ }^{13}$ of TSD alleles. The mutation has caused TSD in a Pennsylvania Dutch kindred, ${ }^{14}$ a Dutch TSD patient, ${ }^{15}$ a Scottish patient, ${ }^{15}$ an American patient (details of ancestry were not reported), ${ }^{15}$ a Mexican patient, ${ }^{12}$ and four patients of unknown ancestry. ${ }^{12}$ The intron 9 mutation has also been found in a Louisiana Cajun person ${ }^{16}$; the Cajun population is of French origin. Thus of the subjects carrying the intron 9 mutation, all but two could trace their ancestry to central or western Europe (of those where ancestral information was known). The $\mathrm{G}$ to A transition has occurred at a $\mathrm{CpG}$ mutation 'hot spot' and therefore has an increased chance of recurrence. However, this mutation has now been reported in so many non-Jewish TSD patients that an independent mutational event in each case seems unlikely. Perhaps a more reasonable explanation is that some of these apparently unrelated patients do have common origins; haplotype analysis will be needed to determine whether they share a common genetic background. Recurrence might explain the presence of this mutation in subjects of completely different ethnic origin, such as the Mexican patient reported by Akerman et al. ${ }^{12}$

Clearly the intron 9 mutation is a frequent cause of TSD in non-Jewish patients of European origin, and is especially frequent in patients from (or with ancestors from) the British Isles. While studies of European origin TSD patients show a frequency of this mutation of $11 \%$ or $16 \%$, this study of TSD carriers with British Isles ancestry showed the intron 9 mutation to be present in $23 \%$. Our previous study of TSD patients and carriers living in the British Isles showed that the intron 9 mutation accounted for $42 \%$ of disease alleles, and $63 \%$ in patients from Ireland, Scotland, or Wales.

The results of this study confirm the high frequency of the intron 9 mutation in nonJewish TSD carriers with British Isles ancestry, and emphasise the need to screen nonJewish TSD families of European, particularly UK and Irish origin, for this mutation.

We are grateful to Dr M King for referring the Irish TSD patient, and Elizabeth Manners for invaluable help preparing the manuscript. ECL is funded by the Special Trustees of Guy's Hospital; the work of the Paediatric Research Unit is supported by the Generation Trust and the Spastics Society. The continued generous support of the British Tay-Sachs Foundation is particularly acknowledged. The California Tay-Sachs Disease Prevention Pro- 
gram is supported by a contract from the Genetic Diseases branch of the California State Department of Health, and a grant from the National Tay-Sachs Disease and Allied Disorders Assoc, Inc.

1 Sandhoff K, Conzelmann E, Neufeld E, Kaback M, Suzuki $\mathrm{K}$. The $\mathrm{G}_{M 2}$ gangliosidoses. In: Scriver $\mathrm{CR}$, Beaudet $\mathrm{AL}$ Sly WS, Valle D, eds. The metabolic basis of inherited disease. 6th ed. New York: McGraw-Hill, 1989:1807-42

2 Myerowitz R, Hogikyan ND. A deletion involving Alu sequences in the $\beta$-hexosaminidase $\alpha$-chain gene of French Canadians with Tay-Sachs disease. $\mathcal{F}$ Biol Chem 1987;262:15396-9.

3 Bayleran J, Hechtman P, Boulay B, Andermann E, Cagne $\mathrm{R}$, Kolodney E. Infantile Tay-Sachs disease in FrenchCanada is caused by more than one mutant allele. $A m \mathcal{F}$ Hum Genet 1988;43:A2.

4 Myerowitz R, Costigan FC. The major defect in Ashkenazi Jews with Tay-Sachs disease is an insertion in the gene for I Biol Chem 1988;263:18587-9.

5 Myerowitz R. Splice junction mutation in some Ashkenazi Jews with Tay-Sachs disease: evidence against a single
defect within this ethnic group. Proc Natl Acad Sci USA 1988;85:3955-9.

6 Arpaia E, Dunbrille-Ross A, Maler T, et al. Identification of an altered splice site in Ashkenazi Tay-Sachs disease

7 Ohno K, Suzuki K. A splicing defect due to an exon-intron junctional mutation results in abnormal $\beta$-hexosaminidase $\alpha$-chain mRNAs in Ashkenazi Jewish patients with Tay-Sachs disease. Biochem Biophys Res Commun 1988;153:463-9.
8 Akli S, Chelly J, Lacorte JM, Poenaru L, Kahn A. Seven novel Tay-Sachs disease mutations detected by chemical mismatch cleavage of PCR-amplified cDNA fragments. Genomics 1991;11:124-34.

9 Landels EC, Green PM, Ellis IH, Fensom AH, Bobrow M. $\beta$-hexosaminidase splice site mutation has a high frequency among non-Jewish Tay-Sachs disease carriers from the British Isles. F Med Genet 1992;29:563-7.

10 Triggs-Raine BL, Mules EH, Kaback MM, et al. A pseudodeficiency allele common in non-Jewish Tay-Sachs carriers: implications for carrier screening. Am $\mathcal{f}$ Hum Genet 1992;51:793-801.

11 Mules EH, Hayflick S, Miller CS, Reynolds LW, Thoma GH. Six novel deleterious and three neutral mutations in the gene encoding the $\alpha$-subunit of hexosaminidase $A$ in non-Jewish individuals. Am $\mathcal{F}$ Hum Genet 1992;50:834 41.

12 Akerman BR, Zielenski J, Triggs-Raine BL, et al. A mutation common in non-Jewish Tay-Sachs disease: frequency and RNA studies. Hum Mutat 1992;1:303-9.

13 Akli S, Chelly J, Kahn A, Peonaru L. A null allele frequent in non-Jewish Tay-Sachs patients. Hum Genet 1993;90:614-20.

14 Mules EH, Hayflick S, Dowling CE, et al. Molecular basis of hexosaminidase A deficiency and pseudodeficiency in the Berks county Pennsylvania Dutch. Hum Muta 1992;1:298-302.

15 Akli S, Chomel JC, Lacorte JM, Bachner L, Poenaru A Poenaru L. Ten novel mutations in the HEXA gene in non-Jewish TSD patients. Hum Mol Genet 1992;2:61-7.

16 McDowell GA, Mules EH, Fabacher P, Shapira E, Blitze MG. The presence of two different infantile Tay-Sachs disease mutations in a Cajun population. Am $\mathcal{Y}$ Hum Genet (in press). 